\title{
Eltérően fejlődő gyermek a családban
}

\author{
Kis Noémi \\ Szegedi Tudományegyetem, Neveléstudományi Doktori Iskola
}

\begin{abstract}
A szocializáció állandó folyamatában a szülö és a gyermek kölcsönösen hatnak egymásra. Ahhoz, hogy megértsük, hogyan befolyásolja a gyermek fejlődését a szülö-gyermek viszony, meg kell ismernünk a szülöi oldalt is, melyröl az eltérően fejlődő gyermek esetében még viszonylag keveset tudunk. A többségitöl eltérően fejlődő gyermek szüleinek mindannyiszor szembe kell nézniük azzal, hogy a gyermek más. Az eltérés típusától, felismerésétöl és súlyosságától függetlenül megfigyelhetők jellemző elsődleges szülöi reakciók, számos negatív érzelem. Az átélt negatív érzelmek kapcsolatrendszeri problémákhoz vezethetnek a szülök között, a szülö és a gyermekek között, de érinthetik a tágabb társas kapcsolatokat is. Számos további stressz-forrással is kell szembenéznie a szülöknek. Ezek mindegyike hatással van az eltérően fejlődő gyermek fejlődésére. A szülők sikeres megküzdésében a társas támogatásnak kiemelt szerepe van. A gyermek szempontjából alapvetö fontosságú az is, hogy a szülők aktívan és tudatosan fogadják el öt, hiszen a fejlődését csak ebben az esetben lesznek képesek optimálisan segíteni. A szakembereknek is ismerniük kell azokat a pontokat, ahol beavatkozva támogathatjuk a családot, melyben a gyermek él, mely meghatározza a fejlődését.
\end{abstract}

Kulcsszavak: eltérően fejlődő gyermek, családi kapcsolatrendszer, szociális támogatás, megküzdés, fejlödés

Tanulmányomban olyan kutatásokat és szakirodalmi forrásokat tekintek át, amelyek rávilágítanak arra, hogy a szülő és a más, azaz a többségitől eltérő módon fejlődő gyermeke milyen jelentős mértékű hatást gyakorolnak kölcsönösen egymásra. Bemutatom, hogy mivel kell szembenéznie annak a szülőnek, aki azzal szembesül, hogy egészségesnek várt/hitt gyermeke nem az, illetve kitérek arra is, hogy a szülö-gyermek viszony hogyan határozza meg az eltérő gyermekek fejlődését.

Az eltérően fejlődő gyermek mássága sokszínű lehet, különbségek lehetnek abban, ahogy az eltérés kiderül - maga a szülő veszi észre, a környezet hívja fel a figyelmet vagy szakembertöl érkezik visszajelzés, diagnózis. Más-más lehet az életkor is, amikor fény derül a gyermek másságára - a születéskor vagy későbbi életkorban válik nyilvánvalóvá; organikus eredetű vagy külső hatás következménye. Különbségek lehetnek a másság tartósságában is - esetenként időlegesen áll fenn, míg máskor élethosszig kell hátrányokkal küzdeni. Illetve az is meghatározó, hogy milyen jellegü, milyen súlyosságú a fejlődési eltérés. Mindez befolyásolja azt, ahogy a szülők megélik a helyzetet, azt, hogy hogyan és milyen mértékben küzdenek meg a gyermek másságának tényével. Vannak azonban olyan általános jellemzők, amelyek tipikusan megjelennek. Átfogó képet kívánok adni ezen általános jellemzők bemutatásával, illetve a gyermek fejlődésére gyakorolt hatások megvilágításával. Nem célom kiemelni sem egy adott eltéréssel jellemezhető csoportot, sem életkort vagy súlyossági fokot, csupán az eltérés tényét veszem figyelembe.

Az alábbiakban tehát elemzem, hogy mi történik akkor, amikor a szülő szembesül azzal, hogy nem olyan a gyermeke, amilyet elképzelt, milyen elsődleges reakciók jelenhetnek meg ennek következtében. Kitérek arra, hogy az ekkor átélt negatív érzelmek milyen hatással lehetnek a család kapcsolatrendszerére, a kapcsolatrendszeri 
nehézségeken túl milyen stressz forrásokkal kell megküzdeniük az eltérő gyermeket nevelő szülőknek. Felvázolom a gyermek másságával való megbirkózás folyamatát, a nehézségekkel való sikeres megküzdésben szerepet játszó fő tényezők körét, valamint a szociális támogatás kiemelt jelentőségét. Választ keresek arra a kérdésre, hogy a fentiek alapján milyen módokon mutatkozik lehetőség a szülőknek való segítségnyújtásra, hogy a gyermek eltérő fejlődése következtében megjelenő negatív hatások enyhüljenek, esetleg elkerülhetőek legyenek. Fel kívánom hívni a figyelmet a gyermek aktív elfogadásának jelentőségére, mely alapvető feltétel ahhoz, hogy a szülők a lehető legnagyobb mértékben segíthessék gyermekük fejlődését az élet minden területén. A tanulmány zárásaként pedig a témával kapcsolatos következtetéseim fogalmazom meg, kiemelve annak fontosságát, hogy az eltérő gyermeket nevelő családokban is alapvető feltétel a pozitív szülő-gyermek viszony a gyermek optimális fejlődése érdekében.

\section{Szembesülés a gyermek másságának tényével}

A megszületett gyermek számára a család a legfontosabb tényező, mely hatást gyakorol rá és befolyásolja fejlődését. Eltérő fejlődés esetén pedig fokozott jelentőséggel bír, hogy a család, a szülők hogyan kezelik azt a helyzetet, hogy gyermekük más. A gyermek szerves része a családnak, a tagok között dinamikus kapcsolat van, így ha bármilyen hatás éri a családot, következményei lesznek annak minden tagjára vonatkozóan. Az eltérően fejlődő gyermek hatással van a családtagok személyiségfejlődésre, énképére és életminőségére egyaránt (Degovics, 2004; Garai és Kovács, 2014; Hadiyiannakou, loannaou és Tziogkouros, 2007; Kálmán, 1995; Radványi, 1999; 2013).

Ideális esetben a szülő az első pillanattól, sőt, már a születés előtt tejesen elfogadja gyermekét, ráhangolódás és magas fokú odafigyelés jellemzi, már ekkor kialakul egyfajta kötődés a szülők, elsősorban a gyermeket kihordó anya részéről. Abban az esetben, ha a gyermek más, a szülőnek szembesülnie kell azzal, hogy a gyermeknek nem olyan jellemzői vannak, mint amilyenekre számított, amilyeneket elvárt, tehát szembe kerül a másság tényével. Ennek következtében sérülhet a szülő kontrollérzete, hisz nem tudja megváltoztatni a helyzetet és bizonytalanná válhat szülői szerepében. Az eltérés tényének felismerése rendszerint hirtelen éri a szülőt, nem várt esemény történik, ami krízishelyzetet alakíthat ki. Gyakori, hogy mindennek következtében negatív szülői attitűd alakul ki, ami lehet rejtett is. Fontos itt megjegyezni, hogy ebben az esetben nem a gyermekre, hanem a helyzetre vonatkozik a negatív érzelem, azonban a szülő mindennapi érzelmi megnyilvánulásai többnyire félreérthetőek és nem ezt mutatják, csupán a negatív hozzáállás látható a külső megfigyelők számára (Borbély, 2008; Degovics, 2004; Demeter, 2004; Garai és Kovács, 2014; Radványi, 2006b; Sára, 2007; Szautner, Hámori és Beke, 2010; Tóth, 2008).

A fentiek okán zavar keletkezhet a család kapcsolatrendszerében, ami negatívan befolyásolja a gyermek szocializációját, mely oda-vissza hat a szülöre és a gyermekre, így kialakítva egy negatív körfolyamatot. A kapcsolati zavar okai között szerepelhet, hogy a szülő fokozott stresszként éli meg a helyzetet (Becker, Houser, Engelhardt és Steinmann, 1993; Garai és Kovács, 2014; Ha, Ho, Seltzer és Greenberg, 2008), illetve, hogy a negatív emóciókkal való megküzdés során azt érezheti, hogy nem hasznos tagja a társadalomnak és mindez hangulati levertségig, depresszió kialakulásáig, dezorientáltságig is elvezethet (Demeter, 2004; Obeid és Daou, 2015; O’Brien, 2007). 


\section{A család kapcsolatrendszerére gyakorolt hatások}

A család dinamikus kapcsolatrendszere jelentős mértékben meghatározza tehát a gyermek fejlődését. Ezen kapcsolatrendszeren belül a legfőbb kapcsolatok közé a szülők, vagyis az anya és az apa kapcsolatát, a szülö-gyermek kapcsolatát, valamint a szülő és az eltérően fejlődő gyermek testvérének kapcsolatát sorolják. Fontos tényező a család kapcsolatrendszerének vonatkozásában a társas kapcsolat a tágabb családdal és a barátokkal is (Topolánszkyné, 2010).

Egy gyermek születése mindig nagy hatással van a szülőkre és a kapcsolatukra egyaránt. A kezdeti időben minden szülő fokozott stresszt él át és új szerepekkel kerül szembe, eltérően fejlődő gyermek születése esetén azonban ez a kezdeti időszak további stressz forrásokkal is jár és időben is hosszabb ideig tart, ha véget ér egyáltalán. A szülők kapcsolata esetén kiemelik, hogy nagyobb eséllyel válnak el, ha eltéröen fejlődő gyermekük születik, de fontos hangsúlyozni, hogy a háttérben legtöbbször nem a gyermek mássága áll, hanem az, hogy a kapcsolatuk már a gyermek születése előtt sem volt kellően stabil, és az eltérő gyermek születése okozta nehézségeket már nem bírta el (Borbély, 2008; Guralnick, 1997, Sára, 2007). Kutatási eredmények (Ha és mtsai, 2008; Hartley, Barker, Floyd, Greenberg, Orsmond és Bolt, 2010; O'Brien, 2007) szerint nem csak a kezdeti, hanem a későbbi időszakokra is igaz ez. Az érzelmi nehézségek mellett számos családi jellemző is befolyást gyakorol, így a szülők életkora, iskolázottsága, foglalkoztatottsága, megküzdési stratégiái, a házasságkötés ideje, a gyermek jellemzői közül elsősorban a viselkedési problémák mértéke, valamint a születési sorrend és az eltérően fejlődő gyermekek száma a családban is.

A megnövekedett terhek többnyire az anyát sújtják, mert ő marad otthon a gyermekkel, ő az elsődleges gondozó és felelősségvállaló. Mindennek következtében ő él át nagyobb stresszt és ez forrása lehet a szülök közötti feszültségnek. Ha munkát vállal az anya, az további teherként jelenhet meg a számára. Ugyanakkor az apa terhe és felelőssége is fokozott, ha ő válik a család egyedüli fenntartójává (Borbély, Jászberényi és Kedl, 2000; Garai és Kovács, 2014; Lawoko és Soares, 2003; McConachie, 1989; Obeid és Daou, 2015; Sára, 2007). Érzelmileg nagy megpróbáltatásokat él át az apa és az anya is. Jóllétükben nincs kimutatható különbség, aminek a hátterében a nemi szerepek különbségeinek fokozatos csökkenését feltételezik (Ha és mtsai, 2008). Azonban férfiak és nők eltérően mutatják ki az érzéseiket, amit a társadalmi elvárások is jelentősen meghatároznak (Kálmán, 1995), illetve eltérő megküzdési stratégiákat is alkalmaznak az anyák és az apák (Topolánszkyné, 2010).

A szülö-gyermek kapcsolat esetében arra hívják fel a figyelmet, hogy a szülő a pszichés terhek következtében kevésbé érzékennyé válhat a gyermek irányába és egyidejüleg sújthatja fizikai-lelki-szellemi fáradtság, ami fokozza a szülöi feladatok tökéletlenebb ellátását. Az eltérően fejlődő gyermek sajátosságai nagymértékben meghatározzák a szülők viselkedését, a gyermekkel való kapcsolatuk alakulását. A gyermek sajátosságai közül szubjektív magatartása a legmeghatározóbb, az, ahogy a szülö minősíti a gyermeket, ahogy percipiálja a viselkedését (Becker és mtsai, 1993; Borbély, 2008; Demeter, 2004; Garai és Kovács, 2014; O’Brien, 2007). Obeid és Daou (2015) a szülői hozzáállás négy típusát különíti el: 1 . az apa magára hagyja az anyát a gyermekkel, érzelmileg különválik tőlük, 2. a szülök együtt válnak külön a gyermektöl, 3. a gyermek kerül a középpontba, minden más másodlagossá válik, 4. a szülök összefognak a gyermek érdekében és törekednek a normális családokhoz hasonlóan élni.

A szülő és az eltérően fejlődő gyermek testvére közötti kapcsolat vonatkozásában meg kell említeni, hogy a kevesebb szülöi figyelem miatt féltékenység alakulhat ki, 
amivel meg kell birkóznia a szülőnek, az ő igényeit is ki kell elégíteni, rá is kell minőségi időt és energiát fordítani. Ezen felül kezelnie kell az eltérés meg nem értéséből fakadó gyermeki félelmet is, ahogy a gyermek attól való félelmét is, hogy miatta nem jut kellö figyelem vagy bárminemű forrás a testvérére (Kálmán, 1995). Ugyanakkor arra is figyelemmel kell lennie a szülőknek, hogy ne támasszon túl nagy elvárásokat a gyermek felé, ne akarja vele kompenzáltatni a testvére hiányosságait, illetve oldja a gyermek attól való félelmét, hogy negatív következményekkel járhat, ha túlszárnyalja eltérően fejlődő testvérét (Lardieri, Blacher és Swanson, 2000). A szülőnek a nem eltérően fejlődő testvérrel való kapcsolatát számos tényező befolyásolja, amelyek közül a testvérsorrendet, a testvérek számát, életkorát, nemét és egészségi állapotát, a család anyagi helyzetét, a szociális izoláltság/integráltság mértékét és az eltérően fejlődő gyermek másságának mértékét emelik ki elsősorban (Borbély és mtsai, 2000; Tudor és Lerner, 2015).

Az eltérően fejlődő gyermek megbolygatja a család rendszerének egyensúlyát, késlelteti a család fejlődését, lelassítja normális életritmusát. Az ilyen, nem hagyományos családi életciklusban négy válságidőszak különíthető el. Az első ilyen időszak, amikor a szülők felismerik és szembesülnek azzal, hogy gyermekük más, illetve amikor igyekeznek megismerni a másság okait és következményeit. Ez idő alatt számos negatív érzelemmel kell megbirkózniuk. A második válságidőszak akkor érkezik, amikor a gyermeknek már szaksegítségre van szüksége a fejlődéshez, amikor a család szolgáltatásokat vesz igénybe. Ekkor a szülő már mindenképpen szembesül a környezet reakcióival, ha korábban még el is tudta kerülni, illetve mindennapi, sokszor ellentmondásos és feszültségekkel, konfliktusokkal teli kapcsolatba kerül a szakemberekkel. A harmadik válságidőszakkor a gyermek elhagyja az iskolát és a szülőnek meg kell birkózni a hogyan tovább kérdésével, gondoskodnia kell a fiatal ellátásáról, figyelembe véve a szülőkről való leválás lehetséges és optimális mértékét. A negyedik válságidőszak akkor jön el, amikor a szülő már nem tud maga gondoskodni gyermekéröl, ami miatt ismét az aggodalom, a szégyenérzet és a búntudat uralkodhat el rajta. Megoldva a kríziseket új, magasabb szintű egyensúlyt hoz létre a család. Súlyos következményekkel jár, ha nem tud sikeresen túljutni ezeken az időszakokon. Végső esetben a család szétesését is okozhatja, ha állandó krízishelyzetben élnek a tagok (Ha és mtsai, 2008; Kálmán, 1995; Komlósi és Antal, 2004; O’Brien, 2007; Radványi, 2006b, Topolánszkyné, 2010).

Óvatosabb megfogalmazás szerint a másság nehezítő körülmény a család életében, ami megváltoztatja a müködését, de ez a változás nem egyértelmüen és nem feltétlen negatív. Csak a család rugalmasságában van eltérés az ép gyermeket nevelő családokhoz képest (Garai és Kovács, 2014). Csökkenhet viszont a család összetartozásának érzése, különösen, ha a gyermek korlátozottan képes csak kommunikálni (Guralnick, 1997; Radványi, 2013). A korlátozott kommunikáció szintén negatívan hat a szülöi kompetenciaérzésre. Valamint kisebb örömforrást jelenthet a gyermek a szülő számára, mert például nem tudja kimutatni, hogy örül a szülö megjelenésének (Hamilton és mtsai, 2015; Radványi, 2006b).

\section{Az eltérően fejlődő gyermek szüleit érő stressz forrásai}

A család kapcsolatrendszeri nehézségein felül számos olyan stresszforrás azonosítható, amelyekkel meg kell küzdenie az eltérő fejlődésű gyermeket nevelő szülőknek. Az egyik ilyen, hogy az eltérően fejlődő gyermek szülei speciális helyzetbe kerülhetnek azáltal, hogy esetükben a szülőség meghatározhatatlan idejü a gyermek gondozása, nevelése vonatkozásában és emiatt a megterhelésük sem csak átmeneti jellegü (Topolánszkyné, 2010). A gyermek állapota akár minden nap új kihívások elé állíthatja 
a szülőket, akiknek felkészültnek kell lenniük a mindenkori aktuális helyzetre és az állandó bizonytalanságra (Hamilton, Mazzucchelli és Sanders, 2015; O’Brien, 2007).

A gyermekkel való nagyarányú vagy állandó együttlét következtében kevesebb idő és energia jut minden másra. Módosulnak a család céljai és a családi aktivitás is. Korlátozódnak a szabadidő eltöltésének módjai és időkeretei. Visszaesik a szülői munkavállalás és karrierépítés lehetősége. Problematikusabbá válik a további gyermek vállalásának kérdése. Az eltérően fejlődő gyermek sok esetben az egyedüli gyermeke a szülőknek, így más gyermek esetében sem tudják megélni szülői kompetenciájukat (Borbély, 2008; Borbély és mtsai, 2000; McConachie, 1989). Mindemellett a hosszú távú célok kis jelentőséget kapnak, mert a mindennapi tevékenységek túl nagy energiaráfordítással járnak, illetve a távoli jövő sok esetben nem mutat pozitív képet. A családtagok saját és közös céljai helyett a kiemelt szerep az eltérően fejlődő gyermeké. Több feladat, nagyobb fokú időbeli kötöttség és megnövekedett anyagi terhek jellemzik a családot. Sok esetben szükséges a lakáskörülmények átalakítása is (Lawoko és Sanders, 2003; Radványi, 2013).

A szülő neheztelhet a megnövekedett terhek miatt. De büntudatot is átélhet (Borbély, 2008; Hámori, 2001; Lawoko és Soares, 2003). Bünbakot láthat a gyermekben és önmagában, vagy a másik szülöben egyaránt. Szégyent érezhet, amiért gyermeke nem tökéletes. Ezt az érzést pedig jelentősen fokozhatja a környezet hozzáállása. Mindennek következtében a gyermeket nyíltan vagy burkoltan elutasíthatja (Becker és mtsai, 1993; Kálmán, 1995; Radványi, 2013; 2006b; O’Brien, 2007).

Jellemzően szociális elszigetelődés figyelhető meg, melynek oka lehet a rokonok csalódottsága, a korlátozott mozgáslehetőség és a gyermeket érő negatív hatásoktól való félelem egyaránt. További ok lehet a család vélt vagy valós kiközösítése, az esetleges stigma, az előítéletek, a család szándékos visszahúzódása, a gyermek gondozásába való túlzott mértékű belefeledkezés (Borbély és mtsai, 2000; Ha és mtsai, 2008; Lawoko és Soares, 2003; Radványi, 2006b; 2013) és a meg nem értés érzése is (Degovics, 2004). Alátámasztja mindezt az a megállapítás, mely szerint általános társadalmi nézet, hogy a másság teher és ezt a terhet a családnak, elsősorban a szülöknek kell viselniük, a társadalmi támogatás legfeljebb anyagi jelleget ölt (Rozsos és Krémer, 2009).

\section{A gyermek másságával való megbirkózás, a gyász folyamata}

Annak, hogy a szülő megküzdjön a gyermek másságából fakadó nehézségekkel, az elfogadás az alapja, melynek különböző szintjei lehetségesek. Ezeken valamennyi szülő végigmegy, de számos tényező befolyásolhatja, hogy eljut-e a tudatos elfogadás szintjére, hogy milyen gyorsan jut át az egyes szinteken és hogy milyen mértékü, vagy hányszori visszaesés történik. A legfőbb befolyásoló tényezők között a gyermek jellemzőit, a szülők jellemzőit (személyiség, sebezhetőség, életkor, iskolázottság), a család jellemzőit (méret, anyagi források, értékrendszer), illetve a kultúra és a környezet hozzáállását említik. A szülői elfogadást befolyásolja az is, ha az anya és a csecsemő elszakad, mert ebben az esetben nem tud kialakulni a korai kötődés. Meghatározó továbbá, hogy mikor és hogyan közlik a szülővel a másság tényét, hogyan kezelik, kezelik-e a közlést követő sokkos állapotot (Belsky, 1989; Garai és Kovács, 2014; Kálmán, 1995; Obeid és Daou, 2015).

A másság felismerésekor, elismerésekor veszteségélmény éri a szülőt, mert nem született meg az a gyermek, akit várt, a várt gyermek elvesztését, hiányát pedig annak szimbolikus halálaként éli meg, ami gyászfolyamatot indít meg. Ennek során gyászolja elképzelt gyermekét, akit elvesztett, gyászolja jövőben elképzelt önmagát és gyászolja a 
megszületett, de nehézségekkel küzdő gyermekét. A gyászfolyamat befejezése a gyermek elfogadásának feltétele. A környezet olyan jellegű reakciója, hogy „Ne sírj, hisz él a gyermek!”, vagy, hogy önfeláldozást várnak a szülőtől, gátolja a gyászfolyamatot, ahogy az is, hogy ebben a gyászban nem tud osztozni a környezettel a fájdalmában, mert mások nem tudják átérezni a helyzetét, vagy nem is akarják. Emellett a gyermek valójában nem halott, sőt, foglalkozni kell vele, ami miatt kevesebb ideje és energiája jut a szülőnek saját lelki problémái rendezésére, a gyász megélésére (Borbély, 2008; Borbély és mtsai, 2000; Degovics, 2004; Hámori, 2001; Kálmán, 1995; Polcz, 2007; Radványi, 1999).

Kárpáty (2002) szerint a gyász négy fázisa különíthető el: szembesülés, kontrolláltság, tudatosulás és adaptáció. A szembesülésre adott válasz egyénenként és a körülményektől függően is eltér. A sokk csak egy lehetséges reakció, ahogy a megkönnyebbülés vagy a tagadás is. A kontrolláltság szakasza a hivatalos tennivalók elintézésnek idejét jelenti, amely időben kitolja, ugyanakkor előkészíti a tudatosulást. Fokozott szerepe van ebben a fázisban a gyászoló támaszrendszerének, melybe a házastárs, a család és a környezet egyaránt beletartozik. A tudatosulás szakasza a leghosszabb és egyben a legmegterhelőbb, ilyenkor eluralkodnak a negatív érzelmek, a szomorúság, düh, önvád és a gyászoló túlzottan befelé fordul, vagy ellenkezőleg, túlzott aktivitásba menekül. Az adaptáció szakasza az elfogadással kezdődik, csökkenni kezd a korábbi befelé fordulás, megindul a jövő tervezése .

A gyászfázisok és az elfogadás szintjeit összevetve a bizonytalanság szintjén tartó szülő látja, hogy a gyermeke nem olyan, mint a többiek, de sokáig próbálja a gyanút elnyomni magában. A bizonyosság szintjén már közelít az igazsághoz, de még elutasítja azt. Amikor megtörténik a diagnózis közlése, megtörténik a szembesülés is. A lázadás szintjén agresszió, tiltakozás, ok és bűnbakkeresés, illetve izoláció jellemzi a szülőt. A következő szint a sorssal való egyezkedéssel írható le. Ekkor gyógyító eljárásokat keres a szülő és reménykedik a csodában. Az elfogadás felé vezető út utolsó előtti szintje a szomorúságé, amikor depresszió, bánat, levertség és a veszteség élménye uralkodik el. Ezeken túljutva történhet meg az aktív tudatos elfogadás. Ide eljutni azonban nagyon nehéz, a visszaesés szinte természetes és sokaknak csak segítséggel sikerül túljutni a szinteken (Radványi, 2013).

Az elfogadás szintjeinek egy másik, de a fentiektől lényegileg nem különböző elkülönítése szerint az első a sokk fázisa, ahol jellemző szülői reakció a tagadás, az elszigeteltség, a meg nem értettség érzése, a szégyen, a bizonytalanság és a jövőtől való félelem, valamint mindennek következtében a környezettől való valódi elszigetelődés. Nagy segítséget jelenthet ekkor az olyan szülővel való kapcsolat, aki már sikeresen túljutott ezen a szakaszon. A kezdeti sokkot a harag követi. A szülő igazságtalannak tartja a történteket, büntudatot és kiszolgáltatottságot érez, haragszik az őt ért szerencsétlenség miatt, haragszik a gyermekre, a házastársára, a szakemberekre és önmagára is. Jó, ha ilyenkor lehetőséget kap a harag levezetésére, segítséget a valódi kiváltó ok felismerésére és minél pontosabb válaszokat az őt nyugtalanító kérdésekre. Az alku fázisát a láthatatlan hatalomnak tett ígéretek jellemzik és a gyermek mindenek fölé helyezése. Nagyon fontos ilyenkor segíteni a szülőt, hogy csökkenteni tudja az önmaga feláldozásának késztetését és ráirányítani a figyelmét az eltérően fejlődő gyermeken túli világra, és a családtagokra. A depresszió szintjén a gyermek szeretetének és gyülöletének érzése váltakozik, kiegészülve a gyülölet miatt érzett büntudattal és a mély bánattal. Ekkor segítséget jelenthet a szülő számára, ha figyelmét a gyermek pozitívumai felé terelik. A valódi elfogadás akkor történhet meg, ha megismeri és megszereti gyermekét, olyannak szereti, amilyen, képes újra felfedezni az örömöt és pozitívan tekinteni a jövőbe. Mindehhez pedig nagyban hozzájárulhat a társadalmi elfogadás (Kálmán, 1995). 


\section{A szociális támogatás kiemelt szerepe a gyermek másságával való sikeres megküzdésben}

A gyermek mássága okozta nehézségekkel való sikeres megküzdést, a krízis mélységét és tartósságát elsősorban nem a gyermek vagy a szülők egyéni jellemzői, hanem a környezet (házastárs, rokonok, barátok, szakemberek, más hasonló helyzetü szülök, a szükebb és tágabb közösség) hozzáállása határozza meg. A gyermek mássága következtében fellépő negatív hatások jelentősen csökkennek, ha a környezet támogatást nyújt, de a legideálisabb, ha mindhárom tényező a pozitív irányba segíti a szülőt (O’Brien, 2007). A támogatás alatt több tényező is érthető. Az egyik, hogy kulturális rutinokkal segítheti a szociális környezet a feldolgozást, a helyzet kezelését. Ettől azonban még messze vagyunk a mindennapok gyakorlatában, az eltérően fejlődő gyermek esetében nincsenek segítő társadalmi megküzdési rutinok, nincsenek nevelési minták a szülők elött, ezért nagy felelősség hárul a szakemberekre a mintaadásban (Obeid és Daou, 2015; Radványi, 2013). A környezet több módon is támogathatja a szülőt. Az emocionális támogatás keretében szeretetet és interperszonális elfogadást közvetít felé. Az instrumentális segítség tárgykörébe tartozik az információszolgáltatás, a tanácsadás, a feladatellátásban való segítés és a gyermek felügyelete. A harmadik támogatási funkció a szociális elvárások közvetítése, mellyel irányt mutat a szülő számára az adekvát viselkedésre vonatkozóan (Belsky, 1989). Különbséget tehetünk formális és informális szociális támogatás között is. A formálison a hivatalos szervezetek segítségnyújtását, informálison pedig a család érzelmi támogatását értik. Utóbbinak nagyobb jelentőséget tulajdonítanak az eltérően fejlődő gyermeket nevelő szülők megküzdésének sikerességében. A szociális támogatás hatékonyságát két tényező határozza meg elsősorban. Az egyik, hogy mennyire érzékeli elérhetőnek a támogatást a szülő, a másik tényező pedig a támogatás minősége (Obeid és Daou, 2015).

A szociális támogatásban különösen nagy a család szerepe. Képes az érzelmi teherbírás növelésére azáltal, hogy segíti a szülőt negatív érzelmei kezelésében, érettebb reakciómódokat mutatva a számára, megértéssel és szeretettel támogatva a mindennapokban. A hatékony támogatásnak azonban feltételei vannak, melyek között kiemelt jelentőséggel szerepel a nyílt és őszinte kommunikáció (Garai és Kovács, 2014), a kiegyensúlyozott személyközi kapcsolat és a megfelelö összhang a család és a tágabb környezet között (Komlósi, 1997).

A családi támogatás különösen fontos eleme, hogy a szülők segítsék egymást (Hamilton és mtsai, 2015). A házastársi kapcsolat a legfontosabb támogató rendszer a szülők számára (Belsky, 1989; Borbély, 2008). Ha kapcsolatuk kiegyensúlyozott és stabil, még jobban összekovácsolódnak és az így alakult egységfront könnyebben néz szembe a nehézségekkel is. A szülői kölcsönös támogatásba az érzelmi megsegítés mellett az is beleértendő, hogy lehetőség szerint az anya is munkát vállal, amivel növekedhet az önbecsülése. Ennek feltétele, de ettől függetlenül is fontos tényező, hogy az apa is vegyen részt a gyermek nevelésében, gondozásában, mert az anyai terhek csökkentésével saját szülöi kompetenciaérzete is növekedhet (Becker és mtsai, 1993; Garai és Kovács, 2014; Belsky, 1989; Borbély, 2008; Guralnick, 1997; Radványi, 2006a; 1999; Sára, 2007; Tóth, 2008).

\section{A gyermek másságával való sikeres megküzdésben szerepet játszó néhány további tényező}

A gyász mélységére és feldolgozására nagy befolyással van a szociális támogatáson túl, hogy milyen módon és körülmények között szembesül az eltérés tényével a szülö. 
Nagyon fontos lenne már a szembesülést követően azonnal, illetve diagnózis ismertetése során megindítani a pszichológiai támogatást. Az ajánlások szerint lehetőleg már a diagnózis közlésekor mindkét szülő legyen jelen, ne mások előtt történjen, viszont a gyermek legyen ott és lehetőség szerint a szülő tartsa a karjában, ezzel is erősítve az összetartozás érzését. Mivel a közlés következtében sokk éri a szülöket, kiemelt jelentősége van annak, hogy a szakemberek készek legyenek az információkat újra és újra elmondani és a szülők valamennyi kérdésre válaszolni, pontos és érthető diagnózist adni. Mindezzel csökkenthető a szülők szorongása. Fontos továbbá, hogy a negatívumok mellett a pozitív tulajdonságokat és a képességeket is megismerje a szülő, mert így a gyermek erősségeivel is szembesül, ami a pozitív attitűdöt fogja erősíteni benne a gyermek felé. A pszichológus által nyújtott mentálhigiénés támogatás céljai között szerepel, hogy erősödjön a szülö kompetenciaérzete, elismerje, hogy gyászol, felismerje, hogyan élhetnek teljes családként, terepet kapjon a pozitív és negatív érzelmeinek kibeszélésére egyaránt, mobilizálja a szociális támogatást, elérje, hogy a szülő beszéljen a hozzá közelállóknak a gyászról és a nehézségeiről, felvegye a kapcsolatot más hasonló szülőkkel, megismerje az igénybe vehető szolgáltatásokat, segítséget kapjon a gyermek jövőjének tervezéséhez, mindezzel csökkentve a szülő által megélt terheket, valamint, hogy segítsen a szülők félelmét, bủntudatát, önvádját feloldani és erősíteni a pozitív jövőbe tekintést (Borbély és mtsai, 2000 Demeter, 2004; Garai és Kovács, 2014; Guralnick, 1997; Hadiyiannakou és mtsai, 2007; Hamilton és mtsai, 2015; Kálmán, 1995; O’Brien, 2007; Radványi, 2013; 2006b; Sára, 2007).

Kiemelt jelentőséggel bír az is, hogy lehetőség szerint mindkét szülő és az eltérően fejlődő gyermek testvére is vegyen részt aktívan a terápiában és a gondozásban, mert ennek szorongáscsökkentő hatása is van azon pozitív hozadékon felül, hogy megfelelöbb otthoni ellátásban részesülhet a gyermek. A sikeres megküzdés összekovácsolja a családot, ami erőt ad az egyéni problémák kezeléséhez is. A család összetartozás-érzésének növelésére kommunikációs nehézségek esetén például kiemelt módszer az alternatív kommunikációs formák alkalmazása, melyben a szülök adaptációs készsége is megnyilvánul, tehát az, hogy mennyire akarnak és mennyire tudnak változtatni és az adott körülményekhez alkalmazkodni (Becker és mtsai, 1993; Borbély, 2008; Demeter, 2004; Polcz, 2007; Radványi, 1999).

\section{A tanulás eredményességére gyakorolt hatás}

Az eltérő szocializációval is magyarázható, hogy az azonos képességekkel rendelkező tanulók is eltérően teljesítenek (Hickman és mtsai, 2000). A szocializáció folyamatában pedig általában a szülők játsszák a legfontosabb szerepet. A szocializáció kétirányú folyamat, a szülő és gyermeke között kölcsönhatás van, mely során a gyermek elsajátítja tágabb és szűkebb környezete, családja, szülei által preferált normákat, szabályokat, szokásokat, értékeket, viselkedési formákat. Mindeközben a gyermek is hatást gyakorol a szülöre. Ahhoz tehát, hogy minél pontosabban megértsük, hogyan müködik a szülö-gyermek közötti kölcsönös hatásrendszer, elengedhetetlen, hogy ismeretekkel rendelkezzünk a szülői oldalról is.

Mindinkább sürgető, hogy minél pontosabb képpel rendelkezzünk a családról, melyben a gyermek él, hiszen nemzetközi és hazai vizsgálatok egyaránt igazolták, hogy a családnak meghatározó szerepe van a gyermek személyiségfejlődésében, hatást gyakorol tanulási eredményességére és motiváltságára egyaránt. Ma még kevés információnk van arról, hogy pontosan milyen mechanizmusokon keresztül fejti ki hatását (Busch-Rossnagel és Morgan, 2013; Józsa és D. Molnár, 2013; Józsa és Morgan, 
2014; Józsa és Fejes, 2010), alig vizsgált, hogy a szocioökonómiai háttéren és a szülők iskolai végzettségén túl milyen változók lennének alkalmazhatók a család által kifejtett hatások megragadására, összetettebb jellemzésére (Józsa, Wang, Barrett és Morgan, 2014; Wang, Morgan és Biringen, 2013). Kevéssé ismert, hogy milyen pontokon lenne lehetőség a beavatkozásra, segítségnyújtásra a gyermek fejlődésének segítése érdekében. Az eltérően fejlődő gyermekek esetében még kevesebb információ van a birtokunkban, azonban a tipikusan fejlődő gyermeket nevelő családok sok esetben mutathatnak hasonlóságot az atipikusan fejlődő gyermeket nevelőkkel a hatásrendszer tekintetében, így az alábbiakban ismét az általános jellemzők kerülnek kiemelésre.

A családi háttér esetében kiemelt terület a szülö-gyermek viszony elemzése (Safford, Alloy és Pieracci, 2007), mely elsősorban interakciójukban figyelhető meg, ahol a gyermekkel való bánásmód a meghatározó (Eigner, 2012, Solymosi, 2004). A szülői bánásmód azon érzelmi légkörként határozható meg, amelyben a szülő gyermekét neveli (Spera, 2005), amely a szülői figyelemmel, megerősítéssel, biztatással, elfogadással vagy ezek negatív megfelelőivel jellemezhető. Ezen jellemzők ismeretében fontos információk nyerhetőek a szülő és gyermeke viszonyáról (Kis és Józsa, 2014), következtethetünk a gyermek fejlődésére, az esetleges teljesítményzavarok kialakulására, így lehetőség adódik a kellő időben történő beavatkozásra is (Eigner, 2012). A kapcsolat szubjektív megélése befolyásolja mind a kognitív-, érzelmi- és szociális fejlődést, mind a gyermek szociális viselkedését, későbbi kapcsolatainak alakulását (Eigner, 2012; Solymosi, 2004; Zsolnai, 2001a; 2001b).

A gyermek tanulási motiváltságával a szülők iskolai végzettsége csak gyenge kapcsolatban van, összefüggést mutat viszont a szülői nevelési stílussal és a gyermeknevelés olyan egyéb jellemzőivel, mint a gyermek ösztönzésének különböző módjai. $A$ szülő és gyermeke közötti interakció, a szocioemocionális tényezők, a fizikai környezet és a szülői nevelési stílus befolyásolásával, azon belül pedig a szülői ösztönzés és szeretet-törődés szintjének növelésével, valamint a szülői korlátozás-túlvédés mértékének csökkentésével, illetve a büntetés elkerülésével, az elsajátítási motívumok alakíthatóak, adott esetben fejleszthetőek (Kis, 2013; 2015; Kis és Józsa, 2012).

A tanulás eredményességére vonatkozóan a gyermekkel való szülői bánásmód indirekt hatása mutatható ki (de Bruyn, Dekovic és Miejnem, 2003; Darling és Steinberg, 1993). Például a gyermek célorientációi és társas tanulási környezetben való mediálófaktor lehet a két terület között (de Bruyn, és mtsai, 2003). Az autoritatív (demokratikus) nevelési stílus, mely szülői melegséggel, engedékenységgel, a gyermek önállóságának támogatásával és kétirányú kommunikációval jellemezhető, direkt pozitív kapcsolatban áll a tanulási eredményességgel (Erden és Uredi, 2008; Fulton és Turner, 2007). A szülői gondoskodás ugyancsak pozitív, míg a korlátozás-túlvédés negatív összefüggésben van a tanulás sikerességével (Kis, 2013).

Az elsajátítási motívumok fejlődését a szocializációs folyamatok jelentősen meghatározzák. Mivel a szocializáció elsődleges terepe a család, különösen fontos kérdés, hogy a szülők hogyan gyakorolnak hatást a gyermek tanulási motivációjára (Józsa és Fejes, 2010). A szülöi hatások különböző csoportokba sorolhatóak: nevelési gyakorlat, gyermekkel kapcsolatos gondolkodás és a szülö-gyermek kapcsolat jellege (Pomerantz, Grolnick és Price, 2005), kritikus összetevők emelhetőek ki: gyermeket érő stimulusok mennyisége és jellege, gyermek autonómiájának támogatása és biztonságot nyújtó, meleg anyai háttér (Busch-Rossnagel, Knauf-Jensen és DesRosiers, 1995).

A szülők gyermeki motivációra gyakorolt hatásai közül számos tényező befolyása már igazolt. A gyermekneveléssel kapcsolatban átélt anyai stressz esetében azok a gyermekek, akiknek az anyja magas stressz értékeket mutat 6 hónapos korukban, 
jellemzően alacsonyabb elsajátítási motivációs szinttel rendelkeznek másfél évesen (Sparks, Hunter, Backman, Morgan és Ross, 2012). A gyermek iskolai sikereire adott anyai visszajelzéseinek szerepét kutatva a visszajelzések két típusát különítették el: a gyermek személyére és a tanulási folyamatra vonatkozó dicséretet. Igazolt, hogy a személyére vonatkozó dicséret hatására a gyermek kerüli a kihívást jelentő helyzeteket (Pomerantz és Kempner, 2013). Az anyai kontrol időbeli hatását vizsgálva minél magasabb szintủ a kontrol, a gyermek elsajátítási orientációja annál inkább visszaesik fél évvel később, de már azonnal is érzékelhető a visszaesés. Ez azzal magyarázható, hogy a gyermek nem kap elegendő lehetőséget a kihívások önálló megoldására, emellett a szülö azt kommunikálja felé, hogy nem képes befolyásolni környezetét, mindennek következtében a gyermek végül feladja a próbálkozást (Moorman és Pomerantz, 2008).

A biztos kötődéssel jellemezhető anya-gyermek kapcsolat kedvezően hat a gyermek szociális viselkedésére, magasabb motiváltság és teljesítmény, illetve pozitívabb énkép jellemzi. A biztos kötődésű kapcsolatban az anyák nagyobb odaadást, figyelmet és szeretetet tanúsítanak gyermekük felé, továbbá jobban bátorítják gyermekük önállóságra törekvését is. A bizonytalan kötődés ezzel szemben káros hatást fejthet ki a szociális fejlődésre, valamint alacsonyabb motivációt és teljesítményt eredményezhet (Barett és Holmes, 2001; Liu, Li és Fang, 2011; Solymosi, 2004; Zsolnai, 2001a; 2001b).

A gyermek iskolai teljesítménye, képességfejlődése és motivációja szorosan öszszekapcsolódik, kölcsönösen erősíthetik vagy gyengíthetik egymást (Józsa, 2005). Az eltérően fejlődő gyermekek esetében ugyancsak fontos kérdés, hogyan alakul tanulási motivációjuk, teljesítményük és milyen fejlettséget érnek el. Motivációjuk és teljesítményük még szorosabb összefüggést mutat, mint ép fejlődésű társaik körében (Gut, Heckman, Meyer, Schmid és Grob, 2012). Vizsgálati eredmények szerint tanulási motiváltságuk elmarad a kortársaikétól, a feladatmegoldások során kisebb mértékủ kitartást és elsajátítási örömöt tanúsítanak (Gilmore, Cuskelly és Browning, 2015; Gut és mtsai, 2012; JaKyoung, 2012; Waldman-Levi és Erez, 2015), illetve énhatékonyságuk is alacsonyabb (Hadiyiannakou és mtsai, 2007; Hamilton és mtsai, 2015). Kimutatták, hogy az eltérően fejlődő gyermekek szülei nagyobb mértékben avatkoznak bele a gyermek tanulási folyamatába, jobban kontrollálják a gyermeket és mindezzel viszszavetik a motiváció fejlődősét. Ugyanakkor a gyermekek is jobban igénylik a nagyobb fokú szülői segítséget, valamint a teljesítményükre adott visszajelzést és megerősítést (Józsa és Fazekasné, 2007). A tanulásra adott visszajelzések során azonban mindannyiszor fontos figyelembe venni az adott gyermek sajátosságait és önmagához kell viszonyítani (Józsa és Fazekasné, 2007). A gyermeknek adott visszajelzések már az első pillanattól kezdve nagymértékben befolyásolják, hogy a gyermek mennyire szeret tanulni. Ha már kezdetben kedvezőtlen hatások érik a gyermeket, az később fokozhatja a nehézségeket. Meghatározó, hogy milyen elvárásokat tapasztal a gyermek, mert önbeteljesítő jóslatként az elvárások az azt igazoló teljesítményt fogják serkenteni (Sallay, 2004). Nagy jelentősége van tehát annak, hogy a gyermek környezete, azon beül pedig elsősorban a szülők, mit közvetítenek a gyermek felé, mekkora jelentőséget tulajdonítanak a tanulásnak és mennyire segítik a gyermek fejlődését, mennyire erősítik motiváltságát (Józsa, 2007; Waldman-Levi és Erez, 2015).

\section{Következtetések}

A fentiek alapján egyértelmű, hogy a családokat, így az eltérően fejlődő gyermek családját is összetettségében kell tekintenünk. A gyermek fejlődősére gyakorolt szülői hatások vizsgálatakor elkerülhetetlen a szülői oldal feltárása is, tehát a szülőkre 
gyakorolt gyermeki befolyásé, hiszen a szülő-gyermek kapcsolat dinamikus, állandó kölcsönhatást jelent. Ha arra vagyunk kíváncsiak, hogyan segíthetjük a gyermek fejlődését, ismernünk kell a szülői hatásokat és azok gyökereit is. Azonosítanunk kell azokat a pontokat, ahol beavatkozással támogathatjuk a gyermek családját és ezáltal a gyermek fejlődését. Ilyen lehetőség mutatkozik többek között akkor, ha elérjük, hogy a szülők nyíltan és őszintén kommunikáljanak és együttmüködjenek egymással és a szakemberekkel, illetve hogy a környezet támogassa az érintett családot. A környezet támogatása kulcskérdésnek tűnik, hiszen ha a szülőt pozitív hatások érik mind a szükebb, mind a tágabb környezetéből, akkor sikeresebben küzd meg a helyzetével, lép az aktív elfogadás szintjére, nyit az egyre tágabb környezete felé és mindennek következtében a gyermekre is pozitívabb hatást képes gyakorolni, nagyobb mértékben lesz képes segíteni a gyermek fejlődését. A gyermek aktív elfogadása azért is nagy jelentőségü, mert vizsgálatokkal is alátámasztott, hogy az eltérő gyermek nevelésének a negatívumok mellett pozitív hatásai is lehetnek. Ilyen pozitív hatás például a szülők személyiségének fejlődése, egy erősebb, toleránsabb személyiség kialakulása, perspektívaváltás, amin az élet fontos tényezőinek átértékelését és felismerését, illetve az új napok megélésének örömét értik, a családtagok közötti kapcsolatok szorosabbá válása, vagy az egyéb szociális kapcsolatok gazdagodása (McConnell, Savage, Sobsey és Uditsky, 2015).

A környezet támogatását direkt módon nem tudjuk elérni, de számos más ponton lehetőség mutatkozik a családnak való segítségnyújtásra. A különböző szolgáltatások, ellátások kialakításakor és a szakemberek képzésekor is érdemes ezeket figyelembe venni, de mindenkor szem előtt tartva azt, hogy minden család és helyzet egyedi, a gyermek aktuális állapota állandón változhat, más-más módon és mértékben lehet eltérő a gyermek és mások a szülők jellemzői, reakciói is, tehát a maga egyediségében kell megismerni és segíteni a családot. Szükség lenne a mindenki számára elérhető pszichológiai támogató rendszer kialakítására és a megfelelő és elérhető napközbeni ellátás biztosítására. A család egyediségének figyelembe vétele mellett másik nagyon fontos szempont, hogy ne csak a gyermeket, ne csak a szülöket, hanem a teljes családot egységében segítsük, a segítő, terapeuta, orvos, pedagógus és a többi szakember törekedjen az információcserén és nyílt kommunikáción alapuló partnerkapcsolat kialakítására és arra, hogy mind a szülő-gyermek, mind a szülő-szülő, mind a szülögyermek testvére közötti kapcsolat fejlődését egyidejüleg támogassák.

Az eltérően fejlődő gyermekek eredményességére, fejlettségére a szülők még nagyobb hatással vannak, mint hátrányokkal nem küzdő társaik esetében, ezért még fokozottabb figyelmet kell fordítani arra, hogy a család minden téren (fizikai, szociális, érzelmi, értelmi) a lehető legnagyobb támogatást tudja nyújtani a gyermek számára. A gyermek motiváltabbá és a tanulás eredményesebbé tehető, ha a szülő-gyermek interakció pozitív, ha a szülő a gyermeknevelés során a szeretetet, törődést és gondoskodást helyezi előtérbe, és igyekszik kerülni a korlátozást, túlvédést és büntetést.

Célom volt, hogy bemutassam az eltérő gyermeket nevelő szülőket érő érzelmi hatásokat, hogy jobban megértsük, milyen szocializációs körülményekkel kell számolni ezekben a családokban, milyen tényezők állhatnak a gyermeket érő szülői hatások hátterében. Fel kívántam hívni a figyelmet azokra a pontokra, ahol hatékony beavatkozásra mutatkozik lehetőség annak érdekében, hogy a szülők, mint az eltérően fejlődő gyermek állapotát leginkább meghatározó szereplők, minél hatékonyabban segíthessék gyermekük fejlődését. 


\section{Felhasznált irodalom}

Barrett, P. M. és Holmes, J. (2001): Attachment relationships as predictors of cognitive interpretation and response bias in late adolescence. Journal of Child and Family Studies. 10. 1. sz., 51-64.

Becker, P. T., Houser, B. J., Engelhardt, K. F. és Steinman, M. J. (1993): Father and mother contributions to family functioning when the child has a mental delay. Early Development and Parenting, 2. 3. sz., 145-155.

Belsky, J. (1989): A szülőség meghatározói: egy folyamatmodell. Pszichológia, 9. 3. sz., 383-405.

Borbély Sjoukje (2008): A fogyatékos ember családja. In: Csobay Miklósné (szerk.): A Fecske Szolgálat Kézikönyve. Fogyatékos embereket nevelő családok otthonában nyújtott időszakos kísérés és ellátás. Kézenfogva Alapítvány, Budapest, 70-96.

Borbély Sjoukje, Jászberényi Márta és Kedl Márta (2000): Szülők könyve. Értelmileg sérült kisgyermekek neveléséhez. Medicina Könyvkiadó, Budapest.

Busch-Rossnagel, N. A., Knauf-Jensen, D. E. és DesRosiers, F. S. (1995): Mothers and others: the role of socializing environment in the development of mastery motivation. In: MacTurk, R. H. és Morgan, G. A. (szerk.): Mastery motivation: Origins, conceptualizations and applications. Advances in applied developmental psychology,12.,117-145.

Busch-Rossnagel, N. A. és Morgan, G. A. (2013): Introduction to the section three, overview and analysis. In: Barrett, K. C., Fox, N. A., Morgan, G. A., Fidler, D. J. és Daunhauer, L. A. (szerk.): Handbook of self-regulatory processes in development: New directions and international perspectives. Taylor \& Francis, New York and London, 247-264.

Darling, N. és Steinberg, L. (1993): Parenting style as context: An integrative model. Psychological Bulletin, 113., 487-496.

de Bruyn, E. H., Dekovic, M. és Meijnen, G. W. (2003): Parenting, goal orientations, classroom behavior, and school success is early adolescence. Applied Developmental Psychology, 24., 393-412.

Degovics Zsuzsanna (2004): Súlyosan halmozottan sérült mozgáskorlátozott gyermekek szocializációs folyamatáról. Gyógypedagógiai Szemle, 32. 4. sz., 241-256.

Demeter Csilla (2004): Hogyan befolyásolja a szülők korai fejlesztő beavatkozással szembeni elégedettségét az anya terápiában való aktív részvétele, szorongásszintje, valamint a sérült gyermek fejlődése. Gyógypedagógiai Szemle, 32. 3. sz., 173-182.

Eigner Bernadett (2012): Érzelmi- és viselkedészavarok gyökerei: a korai szülői hatások szerepe. Gyógypedagógiai Szemle, 40. 1. sz., 14-24.

Erden, M. és Uredi, I. (2008): The effect of perceived parenting styles on self-regulated learning strategies and motivational beliefs. International Journal about Parents in Education, 2. 1. sz., 25-34.

Fulton, E. és Turner, L. A. (2007): Students' academic motivation: relations with parental warmth, autonomy granting, and supervision. Educational Psychology, 28. 5. sz., 521-534.

Garai Dóra és Kovács Luca (2014): Másképpen müködnek-e a fogyatékos gyermeket nevelő családok? A családi müködés sajátosságai sérült gyermekek családjaiban. Magyar Pszichológiai Szemle, 69. 1. sz., 235-262.

Gilmore, L., Cuskelly, M. és Browning, M. (2015): Mastery motivation in children with intellectual disability: Is there evidence for a Down syndrome behavioral phenotype? International Journal of Disability Development and Education, 62. 3. sz., 265-275.

Gonida, E. N. és Urdan, T. (2007): Parental influences on student motivation, affect and academic behavior. Introduction to the special issue. European Journal of Psychology of Education, 22. 1. sz., 3-6.

Guralnick, M. J. (1997): Effectiveness of Early Intervention for Vulnerable Children: A Developmental Perspective. American Journal on Mental Retardation, 102. 4. sz., 319-345.

Gut, J., Heckman, C., Meyer, C. S., Schmid, M. és Grob, A. (2012): Language skills, mathematical thinking, and achievement motivation in children with ADHD, disruptive behavior disorders, and normal controls. Learning and Individual Differences, 22. 3. sz., 375-379. 
Ha, J-H., Seltzer, M. M. és Greenberg, J. S. (2008): Age and gender differences in the wellbeing of midlife and aging parents with children with mental health or developmental problems: Report of a national study. Journal of Health and Social Behavior, 49. szeptember, 301-316.

Hadiyiannakou, A., loannou, C. és Tziogkouros, C. (2007): Parents of disabled children. The educational system and the everyday challenges. International Journal about Parents in Education, 1. 0. sz., 145-150.

Hamilton, A. Mazzucchelli, T. G. és Sanders, M. R. (2015): Parental and practitioner perspectives on raising an adolescent with a disability: a focus group study. Disability and Rehabilitation, 37. 18. sz., 1664-1673.

Hámori Eszter (2001): A „halott anya életben tartása” - az énszerveződés viszontagságai a korai kapcsolati traumatizáció tükrében. Pszichoterápia, 10. 4. sz., 233-239.

Hartley, S. L., Barker, E. T., Seltzer, M. M., Floyd, F., Greenberg, J., Orsmond, G. és Bolt, D. (2010): The relative risk and timing of divorce in families of children with Autism Spectrum Disorder. Journal of Family Psychology, 24. 4. sz., 449-457.

Hickman, G. P, Bartholomae, S. és McKenry, P. C. (2000): Influence of parenting styles on the adjustment and academic achievement of traditional college freshmen. Journal of College Student Development, 41. 1. sz., 41-54.

JaKyoung, K. (2012): Relationship of self-determination motivation and school adjustment between students with and without learning disabilities. The Korea Journal of Learning Disabilities, 9. 2. sz., 231-248.

Józsa Krisztián (2005): A képességek és motívumok kölcsönös fejlesztésének lehetősége. In: Kelemen Elemér és Falus Iván (szerk.): Tanulmányok a neveléstudomány köréből. Müszaki Könyvkiadó, Budapest, 283-302.

Józsa Krisztián (2007): Az elsajátítási motiváció. Műszaki Kiadó, Budapest.

Józsa Krisztián és D. Molnár Éva (2013): The relationship between mastery motivation, selfregulated learning and school success: A Hungarian and wider European perspective. In: Barrett, K. C., Fox, N. A., Morgan, G. A., Fidler, D. J. és Daunhauer, L. A. (szerk.): Handbook of self-regulatory processes in development: New directions and international perspectives. Taylor \& Francis, New York and London, 265-304.

Józsa Krisztián és Fazekasné Fenyvesi Margit (2007): Tanulásban akadályozott gyermekek tanulási motivációja. Iskolakultúra Online, 1. sz. 76-92.

Józsa Krisztián és Fejes József Balázs (2010): A szociális környezet szerepe a tanulási motiváció alakulásában: a család, az iskola és a kultúra hatása. In: Zsolnai Anikó és Kasik László (szerk.): A szociális kompetencia fejlesztésének elméleti és gyakorlati alapjai. Tankönyvkiadó, Budapest, 134-162.

Józsa Krisztián és Morgan, George A. (2014): Developmental changes in cognitive persistence and academic achievement between grade 4 and grade 8. European Journal of Psychology of Education, 29. 3. sz., 521-535.

Józsa Krisztián, Wang Jun, Barrett Karen és Morgan George (2014): Age and cultural differences in self-perceptions of mastery motivation and competence in American, Chinese, and Hungarian school age children. Child Development Research, 2014. Article ID 803061, 1-16.

Kálmán Zsófia (1995): Bánatkő. Sérült gyermek a családban. BLISS Alapítvány Keraban Könyvkiadó, Budapest.

Kárpáty Ágnes (2002): A gyász szociológiája. MTA Politikai Tudományok Intézete Etnoregionális Kutatóközpont, Budapest.

Kis Noémi (2015): A szülö-gyermek interakció elsajátítási motivációra gyakorolt hatása. In: Tóth Zoltán (szerk.): Új kutatások a neveléstudományokban. Oktatás és nevelés - gyakorlat és tudomány. MTA Pedagógiai Tudományos Bizottsága és Debreceni Egyetem, Debrecen. 198-210.

Kis Noémi (2013): A szülői bánásmód kapcsolata a szocioökonómiai háttérrel, valamint az iskolai tanulás eredményességével. In: Józsa Krisztián és Fejes József Balázs (szerk.): PÉK 2013 - XI. Pedagógiai Értékelési Konferencia: Program - Elöadás összefoglalók. SZTE BTK Neveléstudományi Doktori Iskola, Szeged. 51. 
Kis Noémi és Józsa Krisztián (2014): A kiskamaszok és szüleik vélekedése a szülö-gyermek viszonyról. Iskolakultúra, 24. 2. sz., 19-34.

Kis Noémi és Józsa Krisztián (2012): A szülői nevelési stílus kapcsolata az elsajátítási motivációval. In: Csapó Benő és Tóth Edit (szerk.): PÉK 2012 - X. Pedagógiai Értékelési Konferencia: Program - Tartalmi összefoglalók. SZTE BTK Neveléstudományi Doktori Iskola, Szeged. 88.

Komlósi Piroska (1997): A család támogató és károsító hatásai a családtagok lelki egészségére. In: Gerevich József (szerk.): Közösségi mentálhigiéné. Animula Egyesület, Budapest, 13-34.

Komlósi Piroska és Antal Mária Ildikó (2004): A fejlődés egészsége - az egészség fejlődése. Magiszter, 1. 4. sz., 33-53.

Lardieri, L. A., Blacher, J. és Swanson, H. L. (2000): Sibling relationship and parent stress in families of children with and without learning disabilities. Learning Disability Quarterly, 23. 2. sz., 105-116.

Lawoko, S. és Soares, J. J. F. (2003): Quality of life among parents of children with congenital heart disease, parents of children with other diseases and parents of healthy children. Quality of Life Research, 12. sz., 655-666.

Liu, J., Li, L. és Fang, F. (2011): Psychometric properties of the Chinese version of the Parental Bonding Instrument. International Journal of Nursing Studies, 48. 5. sz., 582-589.

McConachie, H. (1989): Mothers' and Fathers' Interaction with their Young Mentally Handicapped Children. International Journal of Behavioral Development. 12. sz. 239-255.

McConnell, D., Savage, A., Sobsey, D. és Uditsky, B. (2015): Benefit-finding or finding benefits? The positive impact of having a disabled child. Disability \& Society, 30. 1. sz., 29-45.

Moorman, E. A. és Pomerantz, E. M. (2008): The role of mothers' control in children's mastery orientation: A time frame analysis. Journal of Family Psychology, 22. 5. sz., 734-741.

Obeid, R. és Daou, N. (2015): The effects of coping style, social support, and behavioral problems on the well-being of mothers of children with Autism spectrum Disorder in Lebanon. Research in Autism Spectrum Disorders, 10. sz. 59-70.

O'Brien, M. (2007): Ambiguous loss in families of children with Autism Spectrum Disorders. Family Relations, 56. 2. sz., 135-146.

Okagaki, L. és Frensch, P. A. (1998): Parenting and children's school achievement: A multiethnic perspective. American Educational Research Journal, 35. 1. sz., 123-144.

Pomerantz, E. M., Grolnick, W. S., és Price, C. E. (2005): The role of parents in how children approach achievement: A dynamic process perspective. In: Elliott, A. J. és Dweck, C. S. (szerk.): Handbook of competence and motivation. Guilford Press, New York, 259-278.

Pomerantz, E. M. és Kempner, S. G. (2013): Mothers' daily person and process praise: Implications for children's theory of intelligence and motivation. Developmental Psychology, 49. 11. sz., 2040-2046.

Radványi Katalin (1999): Down-szindrómás gyermeket nevelni. Gyógypedagógiai Szemle, 27. 2. sz., 151-152.

Radványi Katalin (2006a): „Feszültségek a fogyatékos gyermek szülei és a szakemberek között" (Prekop, 1982 alapján). In: Dombi Alice (szerk.): A gyógypedagógiai képzés elmélete és gyakorlata. APC Stúdió, Gyula, 37-40.

Radványi Katalin (2006b): Sérült gyermek a családban. In: Várkonyi Ágnes (szerk.): Ismerj meg, ... hogy megérts! Ismeretek a sajátos nevelési igényü gyerekeket gondozó és nevelő szakemberek és családtagok részére. Semmelweis Egyetem Egészségügyi Főiskolai Kar, Budapest, 15-23.

Radványi Katalin (2013): Legbelső kör: A család. ELTE Eötvös Kiadó, Budapest.

Rozsos Kata és Krémer Balázs (2009): Fogyatékos gyermeket nevelni: szerep és csapda. Gyógypedagógiai Szemle, 37. 4. sz, 230-238.

Safford, S. M., Alloy, L. B. és Pieracci, A. (2007): A comparison of two measures of parental behavior. Journal of Child and Family Studies, 16. 375-384.

Sallay Hedvig (2004): Tanári elvárások, visszajelentések és a tanulók ezekre adott reakciói: érvényesül-e, és miként fejti ki hatását a Pygmalion-effektus? In: Mészáros Aranka (szerk.): Az iskola szociálpszichológiai jelenségvilága. ELTE Eötvös Kiadó, Budapest, 132-142. 
Sára Mónika (2007): Állapotfelmérés óvodás korú értelmileg akadályozott gyermeket nevelő családok életéről. „Talán ez is megoldódik...”. Gyógypedagógiai Szemle, 35. 2. sz., 91-102.

Solymosi Katalin (2004): A családi szocializáció jellemzői. In: N. Kollár Katalin és Szabó Éva (szerk.): Pszichológia pedagógusoknak. Osiris Kiadó, Budapest, 74-94.

Sparks, T. A., Hunter, S. K., Backman, T. L., Morgan, G. A. és Ross, R. G. (2012): Maternal parenting stress and mothers' report of their infants' mastery motivation. Infant Behavior and Development, 35., 167-173.

Szantner Judit, Hámori Eszter és Beke Anna (2010): Koraszülő anyák élményvilága. In: Hámori Eszter (szerk.): Kutatás és terápia metszéspontjai - Várandósságtól a felnőttkorig. Pázmány Péter Katolikus Egyetem Bölcsészettudományi Kar, Piliscsaba, 31-38.

Topolánszkyné Zsindely Katalin (2010): Pszichodinamikai sajátosságok eltérően fejlődő gyermekek családjaiban. In: Hámori Eszter (szerk.): Kutatás és terápia metszéspontjai Várandósságtól a felnőttkorig. Pázmány Péter Katolikus Egyetem Bölcsészettudományi Kar, Piliscsaba, 60-65.

Tóth Anikó (2008): Mit kell tudniuk a szülőknek, amikor megváltozik az életük? In: Borbély Sjoukje (szerk.): Kezünkben a diagnózissal. Útmutató sérült kisgyermeket nevelő családok számára. Kézenfogva Alapítvány, Budapest, 21-33.

Tudor, M. E. és Lerner, M. D. (2015): Intervention and support for siblings of youth with developmental disabilities: A systematic review. Clinical Child and Family Psychology Review, 18. 1. sz., 1-23.

Waldman-Levi, A. és Erez, A. B-H. (2015): Will environmental interventions affect the level of mastery motivation among children with disabilities? A preliminary study. Occupational Therapy International, 22. 1. sz., 19-27.

Wang, J., Morgan, G. A. és Biringen, Z. (2013): Mother-toddler affect exchanges and children's mastery behaviors during preschool years. Infant and Child Development, 23. 2. sz., 139-152.

Zsolnai Anikó (2001a): A gyermekkori kötődések szerepe a szociális kompetencia fejlődésében. In: Csapó Benő és Vidákovich Tibor (szerk.): Neveléstudomány az ezredfordulón. Tanulmányok Nagy József tiszteletére. Nemzeti Tankönyvkiadó, Budapest, 143-152.

Zsolnai Anikó (2001b): Kötődés és nevelés. Eötvös József Könyvkiadó, Budapest. 